\section{El taller del artista. Una mirada desde los archivos fotográficos del Instituto del Patrimonio Cultural de España}

\author{
Madrid: Ministerio de Educación, Cultura y Deporte, Subdirección \\ General de Documentación y Publicaciones, 2017
}

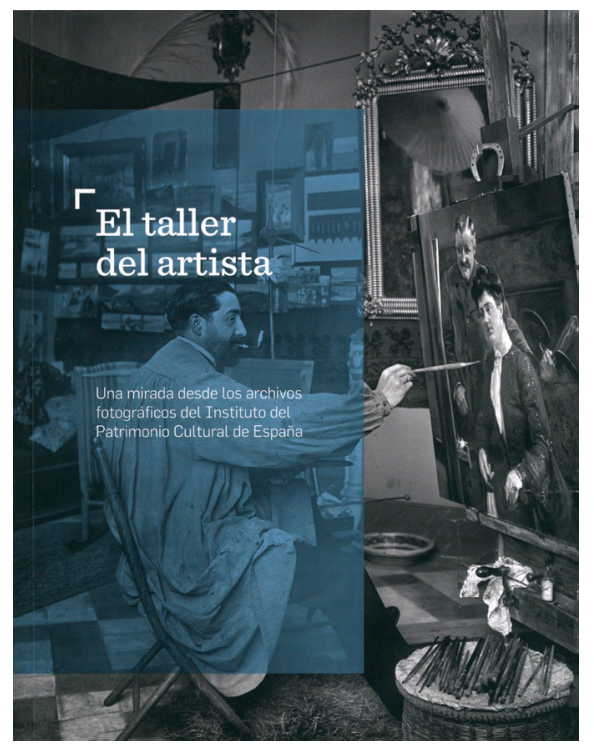

El entorno de trabajo de un artista siempre ha sido objeto de fascinación y curiosidad por la gente. Ya antes de que existiera la fotografía podíamos disfrutar de cautivadoras pinturas donde se representaba al artista en su taller trabajando rodeado de infinidad de objetos y obras, o simplemente con total sencillez frente a sus modelos. El taller del artista es una ventana que nos evoca aquellas pinturas, muchas de ellas del barroco, donde se nos muestra al artista en su lugar de trabajo como El hijo pródigo en la taberna, un autorretrato de Rembrandt de 1635, entre innumerables ejemplos, demostrando que la exaltación por autorretratarse o que te retraten haciendo alguna actividad nunca ha faltado en la historia de la humanidad.

Para situarnos en el contexto del contenido del libro recordemos el apogeo de los cafés literarios en España durante el Romanticismo, reuniones que también se organizaban en los talleres o casas de pintores y escultores, haciendo de la cultura una actividad fundamental hasta que se vio cercenada por la Guerra Civil, cambiando la vida del país y también sus prioridades. A principios del siglo pasado estaba muy de moda fotografiar a los artistas en su lugar de trabajo, era un reclamo para la gente y las revistas de arte. El taller del artista consta de 90 imágenes que recogen dicha temática, seleccionadas del riquísimo archivo del IPCE, Instituto de Patrimonio Cultural de España, y divididas en cinco secciones ordenadas cronológicamente para ofrecer también un relato histórico de la España artística de finales del siglo XIX y principios del siglo XX, pasando antes por una introducción que nos lleva a conocer a los autores de las fotografías y los antecedentes de este género fotográfico, la tarjeta de visita.

La mayor parte de las imágenes son del archivo Moreno (Mariano y su hijo Vicente), pero también hay obras de Ruiz Vernacci, el conde de Polentinos, Otto Wunderlich y Juan Miguel Pando Barrero. Todos ellos excelentes fotógrafos que retrataron a los artistas más famosos de la época. Como se ha mencionado, la guerra frenó y silenció la actividad artística en el país, haciendo que muchos de ellos tuvieran que emigrar y continuar sus carreras en el exilio. De hecho, este libro nos ofrece una maravillosa oportunidad para redescubrir a algunos artistas, entre ellos una mujer, Maruja Mallo, que consiguió hacerse un nombre en un sector aún muy masculinizado. A medida que nos adentramos en la lectura de este libro nos lanzamos a investigar en la vida y obra de los artistas retratados y de aquellos que los retratan porque esas imágenes son como una invitación irrechazable a conocer sus cautivadoras vidas llenas de sofisticación y misticismo. Entramos en estudios que a veces eran palacios, otras veces talleres diáfanos llenos de objetos, 
otras lugares humildes, o las viviendas de los propios modelos. El espacio elegido nos dice mucho de estos artistas. Algunos parecen pertenecer a la aristocracia, posando coquetos, bien vestidos con pincel en mano. Otros, sin embargo, posan con la mayor humildad pero sin denostar el halo místico que entraña su trabajo. El artista se convierte en modelo y posa para otro artista que es el fotógrafo y así entramos en el juego del meta-arte que tanto cautiva al espectador. Quizás sea esa sensación casi hipnótica de este tipo de representaciones lo que haya hecho de esta temática algo tan recurrente durante siglos.

La bellísima introducción de Venancio Blanco ya nos abre la puerta al onírico mundo que se forma alrededor de un artística y que queramos saber más de ellos, objetivo que cumple perfectamente este hermoso catálogo de imágenes.

María del Carmen Hinojosa Corbacho | Máster en Dirección de Comunicación y Relaciones Internacionales

URL de la contribución <www.iaph.es/revistaph/index.php/revistaph/article/view/4613> 